\title{
An Assessment of the Impact of Covid-19 on Small and Medium Enterprises (SMEs) in Lusaka, Zambia.
}

\author{
Dr. Chrine Hapompwe ${ }^{*}$, Caroline Simushi ${ }^{\text {*** }}$, Kiru Sichoongwe ${ }^{\text {** }}$ \\ * Lecturer - Faculty of Social Sciences: Cavendish University Zambia \\ ** Post Graduate Student - Department of Development Studies: Cavendish University Zambia \\ ${ }^{* * * *}$ PhD Candidate - National School of Development: Peking University, China \\ DOI: 10.29322/IJSRP.11.06.2021.p11431 \\ http://dx.doi.org/10.29322/IJSRP.11.06.2021.p11431
}

\begin{abstract}
This study assessed the impact of Covid - 19 on Small and Medium Enterprises (SMEs) in George and Furngroove townships of Lusaka. The study objectives were to establish the business challenges that Small and Medium Enterprises (SMEs) are facing; to ascertain the impact of Covid-19 pandemic on the Small and Medium Enterprises (SMEs), and to determine the level of relief provided by government to SMEs to mitigate the impact of the pandemic. The study collected both qualitative and quantitative data in two townships (George and Furngrove) in Lusaka. Fifty (50) and Forty-eight (48) SMEs were sampled (out of the 2018 4,500 list of registered SMEs in Lusaka) from George and Furngroove townships respectively using convenience and purposive sampling techniques. Data was collected using questionnaires and interview guides. The total questionnaires distributed were 98. The Statistical Package for Service Solutions (SPSS) was used to analyse descriptive statistics while content analysis was applied for qualitative data. Findings from the study established that $48 \%$ of the respondents indicated that the major challenge they faced was the loss of customers due to the outbreak of Covid - 19 with reduced productivity and high cost of doing business being parasitic to the same. On the other hand, majority of respondents represented by $63 \%$ indicated their businesses' revenue reduction of about $50 \%$ as the major impact of the pandemic which occasioned some separation with some workforce and in other cases permanent closure of some business portfolios. Further, the study determined that $57 \%$ of respondents indicated that although the major available support provided by government to mitigate the impact of COVID-19 on their businesses was a financial stimulus package i.e. K10 Billion i.e. $\$ 434$ Million, accessibility remained a challenge owing to labyrinthine accessibility criteria. The findings of the study imply a bleak future of the SMEs ecosystem in Zambia, and bring into question the probability of the country remaining on a firm trajectory towards meeting its 2030 Vision of being a middle income prosperous nation with massive job creation; extensive poverty reduction and meaningful strides on narrowing the gaps on all forms of inequalities. The study recommends that the government through the Ministry of Commerce, Trade and Industry and the Ministry of Finance along with their respective specialised line agencies, must adopt a well-structured, more objective, focused and holistic programmatic approach to deal with the devastating impact of the pandemic as opposed to the current seemingly bureaucratic, haphazard and politicised
\end{abstract}

approach which might not achieve the intended purpose both in the short and long term.

Index Terms- Assessment, Impact, Covid-19, Small and Medium Enterprises, Lusaka.

\section{INTRODUCTION}

$I^{2}$ n developed countries Small and Medium Enterprises (SMEs) play a critical role in many sectors across the economy such as the production, employment and income, in countries like Zambia which are less developed, the SMEs constitute about $97 \%$ of all businesses in the Country. SMEs cut across all sectors of Zambia's economy and provide one of the most high-volume sources of employment and wealth creation and are a breeding ground for industries. The SME sector is viewed as one of the sustainable ways of reducing the levels of poverty and improving the quality of life of households through wealth and job creation as they lean towards employing a large share of the most vulnerable, skilled and unskilled (FSD Zambia, 2017). Small and Medium Enterprises (SMEs) are businesses whose employees fall under a certain threshold. The Zambian government recognised the importance of the SME sector and its contribution to the economic by establishing of the Small Enterprise Development Organisation (SIDO) which later transformed into the Zambia Development Agency (ZDA, 2001). Small and Medium Enterprises are important to all economies of the world, particularly in developing economies such as Zambia. SMEs play an important role in employment, production and income distribution (Oluoch, 2016). According to the Financial Sector Deepening Zambia, Access to Finance: SME perceptions of Financial Service Providers, December 2017 report, SMEs represent $97 \%$ of the businesses, $70 \%$ of gross domestic product (GDP) and $88 \%$ of employment in Zambia. Small and Medium Enterprises in Zambia are mostly run by people from the middle-income bracket and depend mainly on daily cash revenues to sustain their business. The outbreak of COVID-19 is a huge threat to the survival of SME particularly in Zambia (Banking and Insurance, 2020). On January 30, 2020, the 2019 novel coronavirus disease COVID-19 was declared a "Public Health Emergency" by the International Health Regulations Emergency Committee of the World Health Organization (WHO). Covid19 was later declared by the World Health Organisation as a pandemic on $11^{\text {th }}$ March 2020 (Kuckertz, et al., 2020). 
The outbreak has not just been a health crisis but has adversely impacted the economy around the world (Ministry of Finance- 2021 Budget Speech). With the continuous spreading of Covid-19 worldwide which now stands at 110,911,983 total number of confirmed cases and 2,454,254 confirmed deaths as at $19^{\text {th }}$ February 2021 (World Health Organisation), the outbreak has greatly increased uncertainty and the risk of a global recession, broadly defined by the IMF as growth slipping below 2.5 percent a year (Zambia Institute of Public Health, 2020). The global economy activities have contracted as the supply chain reduced the demand for goods and services. This has created a serious consequence as people have lost jobs and millions of livelihoods have been affected as countries implement ways of containing the spreading of the virus and mitigating measures. According to the International Labour Organisation (ILO), over 400 million jobs were lost in the second quarter of 2020 (World Bank Group, 2020a).

As the impact of the pandemic becomes evident worldwide, the global growth forecasts are constantly being adjusted downwards. The International Monetary Fund (IMF) had projected annual global GDP growth of -4.9 percent in 2020 , while the advanced economies were expected to contract by 8.0 percent compared to the growth of 1.9 in 2019. Developing countries and emerging markets were expected to decline by 3.0 percent after positively growing by 3.9 percent in 2019. China is expected td.1. slow to 1 percent in 2020 - by far the lowest growth it has registered in more than four decades (World Bank, 2020a). In Africa, economic activity was projected to decline by 3.2 percent from a growth of 3.1 percent in 2019. Larger economies such as Nigeria and South Africa were projected to decline by 5.4 percent and 8.0 percent respectively, while the Zambian economy was projected to contract by 4.2 percent in 2020 from the earlier projection of 2.6 percent. Almost all the sectors were expected to record negative growth by end of 2020 (2021 Budget SpeechZambia). The supply chain disruptions, market confidence has been significantly damaged, consumer and investment demand are reducing. All these pose a great challenge on the governance of the economy. The mitigating measures that the government had put in place to reduce the spread of the virus had severe impact on sectors such as tourism, education, catering, entertainment, construction, wholesale, retail trade and manufacturing.

On $18^{\text {th }}$ March 2020, Zambia reported the first cases of Covid-19 and to prevent the further spread of the disease, the government directed the closure of all schools, Colleges and Universities. Following the increase in the COVID-19 cases after the initial reported cases in the country, the Government further implemented the following measures among others:

i. Suspension of non-essential foreign travels

ii. Restriction of public gathering to at least 50 people while adhering to the Public Health Guidelines

iii. Adjustment of normal operations of restaurants to only operate on takeaway and delivery basis.

iv. Closure of all Bars, Night Clubs, Cinemas, Gyms and Casinos.

v. Closure of all international airports except for Kenneth Kaunda International

vi. Airport to ensure efficient and effective screening of travellers.
The partial lockdown for Zambia was a necessary step in reducing the further spread of the virus having undertaken various interventions in minimising the spread (National Address on Covid 19 by His Excellency, Mr. Edgar Chagwa Lungu, President of Zambia ,25 ${ }^{\text {th }}$ March 2020). With the partial lock down the country had implemented, Small and Medium Enterprises (SMEs) got affected in one way or the other. The SMEs under focus were:

$\begin{array}{ll}\text { i. } & \text { Bars and Liquor stores } \\ \text { ii. } & \text { Hair Salons and Barbershops } \\ \text { iii. } & \text { Restaurants /Take aways } \\ \text { iv. } & \text { Stock Feed Shops } \\ \text { v. } & \text { Computer /Phone accessories store } \\ \text { vi. } & \text { Supermarket and Minimart Stores }\end{array}$

The government of the Republic of Zambia, noting the likely impact of the pandemic on SMEs, announced a stimulus package through Central Bank amounting to K10 billion which was meant to resuscitate the financial quagmires of these entities. There has not been any study to determine the effect of the pandemic on the SMEs ecosystem nor on the extent of reliefs provided by government to SMEs.

\section{Problem Statement}

Zambia like many other nations around the world has been affected by the pandemic in almost all spheres of socio economic and human exploits as it reported the first cases of Covid-19 on $18^{\text {th }}$ March 2020 (Zambia Institute of Public Health, 2020). As of $6^{\text {th }}$ February 2021, the Ministry of Health had announced Zambia's total number of confirmed cases standing at 61,427 with confirmed deaths at 839 (Zambia Institute of Public Health, 2020). The Covid-19 pandemic has not only brought health challenges but economic challenges as well. Zambia has not been spared from the negative effects of the pandemic as the Government through a multi-sectoral approach working together with cooperating partners introduced measures to prevent the further spread of the disease (Ministry of Health). Unfortunately, these measures turned out to hurt the economy. For example, many SMEs running businesses in education, catering, accommodation, bars, night clubs, gyms and casinos were negatively impacted as most of them could not operate owing to the partial lock down imposed. Businesses that depended on cross border and international trade equally got affected due to the suspension of many airlines to Zambia and to other parts of the world, and the travel restrictions that many countries had implemented (Ministry of Commerce, Trade and Industry, 2020). The economic slowdown resultant from the measures implemented in the fight against the spread of Covid-19 at global and regional levels equally affected the prices of major commodities (Ministry of Finance,2021 Budget Speech). The decline in the copper prices also contributed to the depreciation of the Zambian kwacha by more than $20 \%$ against major currencies thereby negatively affecting the business operations for most of the SMEs (Ministry of Finance, 2021 Budget Speech). According to the Financial Sector Deepening Zambia, despite the easing of restrictions or lifting of the same, SMEs still needed access to working capital and credit facilities to revamp their business operations. The generalities in the effects of Covid-19 pandemic warrants such 
focused and objective studies to determine the actual effects in terms of scale among specific SMEs for a holistic intervention. It is also not clear as to the extent to which the government's announced stimulus package to SMEs was sufficient in mitigating the impact of the pandemic nor did it reach the intended beneficiaries.

\subsection{Objectives}

- To establish the business challenges faced by SMEs in George and Furngrove Townships.

- To ascertain the impact of Covid 19 pandemic on the business revenues of SMEs.

- To find out the level of relief provided by government to the SMEs to mitigate the impact of the pandemic.

\section{THEORETICAL REVIEW OF LITERATURE}

\subsection{Bottlenecks Besetting SMEs}

Zambia recorded its first COVID-19 (coronavirus) case in March 2020 and the cumulative impact on the SMEs has been significant. Macroeconomic challenges and government arrears were testing the resilience of the private sector even before COVID-19, with high treasury yields crowding out lending to the private sector from $15.7 \%$ of gross domestic product in 2015 to $12.4 \%$ in 2019 . These challenges have been exacerbated with women-led SMEs (WSMEs) in particular faced with constrained cash flows and massive reduction in consumer demand.

In the agribusiness sector, the contraction in consumer demand is by far the biggest shock attributed to COVID - 19 . According Mutale (2020), agribusiness includes the processing, packaging and supply of high-value and traditional crops initially saw an uptick in demand after the border lockdown started. But there's been a sharp fall in demand from the hospitality sector and reduced consumer spending as the crisis drags on. Firms in the agriculture have pivoted to cultivate basic crops such as maize and onion, which can be dried and stored, as well as poultry in order to cushion the impact COVID - 19 has brought on the agricultural sector. They have also taken the initiative to diversify into integrating digital platforms like Facebook and WhatsApp to launch home delivery services. The use of digital technologies has helped stabilize some of the revenue losses (CUTS, 2020). Justina's Agro-processing plant, which produces millet meal, porridge and sorghum meal, was temporarily closed during the initial months of the crisis and then was relocated to a larger facility to meet social distancing guidelines. New workers had to be trained and the cost of sourcing inputs from farmers who supply crops or livestock also increased (CUTS, 2020).

Most communications and content creation companies, integrated technology into field research and in outreach campaigns have been a successful undertaking, particularly as non-governmental organization clients continue to focus on public health campaigns. The costs of adhering to social distancing and health guidelines, however, led to increased price points for new clients, making it harder to grow the business. While the focus on public health sector has mitigated some of the immediate impact of COVID-19, the continued uncertainty makes it difficult to plan for the future (BOZ, 2020). According to Bank of Zambia (2020), Women entrepreneurs have validated the findings of the COVID19 Enterprise Survey where more than $86 \%$ of women-led firms reported decreased sales (a similar proportion of male led firms report the same). Nearly $89 \%$ of firms reported decreased liquidity and cash flow with nearly $93 \%$ of women-led firms reporting the same. The workforce impact is also high on female workers - the share of females among the workforce has fall by nearly $8 \%(\mathrm{BOZ}$, 2020).

\subsection{Impact of Covid - 19 Pandemic on Small and Medium Enterprises}

The coronavirus pandemic engendered a global crisis that, unlike most other crises in the world's history, entails both supply and demand shocks. Worldwide, more than twenty million people have been infected as of August 2020, and due to lockdown measures, around 300 million full-time employees have become unemployed or have had a reduction in work hours and pay (International Labour Organization, 2020). The pandemic has affected employment, investment, and growth prospects, and may result in permanent changes in consumption and work patterns (Baldwin, et al., 2020).

Although both large companies and SMEs have been affected by the crisis, recent reviews (Balla-Elliott et al., 2020; Bartik et al., 2020; Dua et al., 2020; Lindsay et al., 2020; OECD, 2020) acknowledge that its effects are greater on SMEs. The OECD summary of 40 surveys in member states and partner countries OECD, (2020) reveals that more than half of SMEs have had substantial revenue loss and fear to be out of business within a quarter unless public assistance is available and extended over the duration of the crisis. There is evidence that SMEs are increasingly digitizing operations to adapt to changing circumstances, but temporary closures, employment and wage reductions, and bankruptcies have occurred. The most widely used policy instruments directed at mitigating the effects of the crisis are income and profit tax deferrals, loan guarantees and direct lending to SMEs, and wage subsidies (OECD, 2020). Small and Mediumscale Enterprises (SME) constitute the majority of businesses in Zambia and play an important role in employment creation and economic growth. The sector is estimated to account for $97 \%$ of all businesses in Zambia contributing $70 \%$ to GDP. Accounting for $88 \%$ of employment, SMEs also play a key role in society as they tend to employ a large share of the most vulnerable segments of the workforce [Consumer Units Trust Services (CUTS),2020]. The Consumer Unit Trust Report of 2020 indicates that SMEs face significant challenges in Zambia particularly in accessing finance thereby limiting their growth potential. In order to address this, the government through the 7NDP emphasizes the creation of a credit guarantee scheme for issuance of low interest, long-term loans to Zambian SMEs, as well as initiatives to accelerate informal sector formalization, foster skill development, create urban industrial clusters, strengthen value-chain linkages and provide business development services to SMEs. Considering the Covid-19, a survey conducted on 98 SMEs in March 2020, 93\% of the respondents indicated that the pandemic has a negative impact on their businesses. Respondents indicated that they were most concerned about the implications that the pandemic would have on their sales, salaries and wages, and rentals (UNECA , 2020). In looking towards the future only $48 \%$ of the respondents indicated that they expected their businesses surviving through the pandemic and the rest either did not see themselves surviving or were unsure. The SMEs indicated that the top three ways that the 
government could assist them during this time was by offering tax exemptions, subsidies and grants. Given the importance of the sector to the economy it will be imperative for the government to put in place measures to protect SMEs, especially in the earlier identified sectors, during this time (BOZ, 2020).

Varshney \& Vyas (2020) conducted a study on the potential impacts of the pandemic on the MSMEs in South Africa. The results of the study indicated that the effects Covid - 19 pandemic on MSMEs is significant in that $69 \%$ of MSMEs reported a decrease in business revenue generation since the beginning of the coronavirus outbreak. The predominant reason for a fall in revenue was a decline in consumer demand for the products $(71 \%)$, followed by supply chain issues $(15 \%)$. Interestingly, the study further revealed that about $14 \%$ of the MMSEs reported an increase in revenue - these were mostly businesses that dealt with essential goods and services, delivery of foods and household goods, and security. Amin et al., (2020) also conducted a study in India to assess the short- and long-term effects of the pandemic on the access to finances by SMEs. The results indicated that access to working capital, by far, was the most cited requirement $(71 \%)$ for businesses to grow and mitigate the adverse effects of the crisis. Those who consider their business as an income source are more likely to identify working capital as the primary constraint (77\%), compared to those who see it as an entrepreneurial venture $(66 \%)$. According to respondents, the least necessary requirement thus far is access to qualified workers and digital literacy skills. Despite the need for working capital, $73 \%$ of respondents have been unsuccessful in raising funds for their businesses to manage the impact of the pandemic. A significant number of respondents (61\%) have already tapped into their own savings for additional sources of funding, followed by another $36 \%$ who have approached family and friends for a loan. Moneylenders are a distant third source (13\%), followed by banks (7\%) (Amin, et al., 2020).

The Ministry of Commerce, Trade and Industry on 3rd July 2020 launched the report of the Business Survey, undertaken with the support from the United Nations Development Programme (UNDP), to assess the impact of the Covid-19 pandemic on various businesses in Zambia. The results of the survey show that Covid-19 had a major impact on businesses in Zambia. Seventyone percent $(71 \%)$ of the respondents indicated that their businesses were partially closed while fourteen percent (14\%) were totally closed. Only fifteen percent $(15 \%)$ reported to have maintained normal operations (UNDP , 2020). The Education, Transport and Catering and Accommodation Sectors have been particularly impacted by Covid-19 while other sectors were almost not affected. Eighty-five percent (85\%) businesses working in education reported were completely closed, while sixty percent $(60 \%)$ of businesses in the human health and social work sector maintained normal operations (Ministry of Commerce, Trade and Industry, 2020).

\subsection{Relief provided by governments to mitigate the impact of the pandemic on SMEs}

In Singapore, the government unveiled several measures to help businesses and SMEs amid the coronavirus outbreak. These measures include wage subsidies to help businesses keep their workers, deferment in income tax payments for companies and self-employed persons for three months, as well as cash pay-outs (World Bank , 2020b).

According to McKibbin \& Fernarndo, (2020) firms received wage subsidies of between $25 \%$ and $75 \%$ for all local workers as part of the Jobs Support Scheme, and eligible self-employed persons (SEPs) were given three quarterly cash pay-outs of $\$ 3,000$ each in May, July and October 2020, as part of the SEP Income Relief Scheme. To further ease cash flow for businesses, the government also announced the enhancement of property tax rebate (for qualifying commercial properties), as well as of various existing financing schemes including the Enterprise Financing Scheme's SME Working Capital Loan, the Loan Insurance Scheme and the Temporary Bridging Loan Programme. The SMEs Go Digital Programme and the Productivity Solutions Grant was also enhanced (Abiad, 2020). In the private sector, Hong Leong Finance (HLF), Singapore's largest finance company, rolled out Covid-19 Loan Relief Schemes to support SMEs and individual customers, and the United Overseas Bank (UOB) allocated \$ 3 billion to provide companies financial relief in the forms of unsecured finance, overdraft facilities, and more (OECD , 2020).

In Hong Kong, starting April, 2020, SMEs were able to tap into loans of up to $\$ 2$ million that was fully guaranteed by the government of Hong Kong. The initiative was under the SME Financing Guarantee Scheme (SFGS) of $\$ 20$ billion to ease the operational burden of SMEs, which was unveiled in the 2020-2021 Budget in February 2020. In the private sector, banks offered to delay repayments or extend loan tenors, and reduced their fees. Some are also unsecured loan products for SMEs and made special arrangements to expedite loan approvals (World Bank, 2020c).

In south Africa, a recent survey done by Retail Capital indicated that 69.8 percent $(68.9 \%)$ of local small and medium enterprises (SMEs) were closed as a result of the national lockdown, with 85 percent reporting a decreased turnover. As such, the South African Government, big businesses and civil society have recognised the impact that Covid-19 is having on local small businesses and have implemented a host of relief packages (Reeves, et al., 2020). The Department of Small Business Development has introduced a "SME Support Intervention" which involved a Debt Relief Fund and a Business Growth/Resilience Facility to mitigate the impact of the expected economic slowdown on SMEs in South Africa. To this effect, the Department made over R500 million available to the Debt Relief Fund, and the SME Finance Scheme will comprise of soft-loan funding for a period of 6 months from 1 April 2020. The Business Growth/Resilience Facility provide working capital, stock, bridging finance, order finance and equipment finance to small businesses which supply in-demand medical supplies. Furthermore, the Department of Tourism has made an additional R200 million available to assist SMMEs in the hospitality and tourism sector (World Bank, 2020d).

In Zambia and as a response to the debilitating effect of the pandemic, the government approved K8 billion kwacha (\$439 million) economic stimulus package financed through a COVID19 bond in an effort to alleviate the pandemic's impact on SMEs. The government also announced a waiver of tax penalties and interest on outstanding tax liabilities resulting from the impact of COVID-19. The Zambia Revenue Authority (ZRA) issued guidelines on the period of relief, waiver qualification criteria and 
other related modalities. The Bank of Zambia, the country's central bank, announced a series of regulatory relief measures for the banking sector. These relief measures are intended to encourage banks, in turn, to provide financial relief to their borrowers (SMEs) (BOZ, 2020). Furthermore, the We-Fi Zambia project is working with the Bank of Zambia (BoZ) and Ministry of Commerce, Trade and Industry to scale up access to finance for WSMEs, through tailored products and services, and through firm capacity building. These are crucial aspects of COVID-19 response and of private sector resilience as Zambian firms seek to recover from the crisis. The program is also more focused on fintech and digital delivery of firm training, especially on financial management skills (Ministry of Commerce, Trade and Industry, 2020). The focus on financial management serves to enhancd.7. credit worthiness of WSMEs during a time when financial institutions are reluctant to lend to SMEs. The key is to prepare viable WSMEs to be better positioned for recovery through a combination of investments and productivity-enhancing tools (BOZ, 2020).

\subsection{Research Gap}

There has been a number of studies conducted around the world on the impact of Covid -19 on the performance of Small and Medium Enterprises since the outbreak of the pandemic. Most of the literature reviewed however is biased to investigating the impact of the pandemic on SMEs focusing much on revenue generation and access to finance. For example, Varshney \& Vyas (2020) conducted a study on the potential impacts of the pandemic on the MSMEs in South Africa. The results of the study indicated that the effects Covid - 19 pandemic on MSMEs is significant in that $69 \%$ of MSMEs reported a decrease in business revenue generation since the beginning of the coronavirus outbreak. The predominant reason for a fall in revenue was a decline in consumer demand for the products $(71 \%)$, followed by supply chain issues (15\%). This study did not look at the impact of the pandemic on employment as well as relief packages that government as well as other donors can provide for these SMEs to mitigate the impact of Covid - 19. Another study conducted by the OECD using a summary of 40 surveys in member states and partner countries. OECD (2020) study revealed that more than half of SMEs have had substantial revenue loss and fear to be out of business within a quarter unless public assistance is available and extended over the duration of the crisis. This study also did not bring out the kind and type of assistance that should be provided to the affected SMEs to navigate through the impacts of Covid 19 on their businesses. In addition, Amin et al., (2020) also conducted a study in India to assess the short- and long-term effects of the pandemic on the access to finances by SMEs. The results indicated that access to working capital, by far, was the most cited requirement $(71 \%)$ for businesses to grow and mitigate the adverse effects of the crisis. Those who consider their business as an income source are more likely to identify working capital as the primary constraint (77\%), compared to those who see it as an entrepreneurial venture $(66 \%)$. This study all did not focus on the relief measures that governments and cooperating partners can implement to help SMEs cope with the effects of Covid-19. The study by the Ministry of Commerce, Trade and Industry (MCTI) in Zambia also dealt with a plethora of issues focusing on the Zambia (the country) as a whole almost in all sectors while the current study is analysing the impact of the pandemic in a defined locality with SMEs only as targets. The study by MCTI also did not pay particular attention to assessing the level of relief offered by government towards mitigating the effect of the pandemic.

As such, there is still inadequate literature on the impact of Covid -19 on the SMEs with regards to their operations, employment as well as the type and kind of assistance or relief that government as well as other donors can provide to help these SMEs navigate through the impacts of the pandemic in Zambia which this study has bridged. In any case, the diversities and differentiations in regional and continental locations could dictate the variations in levels and magnitude of impact of the pandemic. Therefore, there can be no "one-size-fits-all" situation.

\section{Theoretical Framework - Social Capital Theory}

This theory was propounded in 1995 by Putman, which explains social capital as the entire resources both actual and virtual that accrue to an individual owners and organisations by virtue of having mutual relationship, acquaintance and recognition to a social network (Bebbington \& Perreault , 1999). The benefits accumulated through social networks define the social capital of enterprises. This is much essential in the financing context of SMEs because there could be mutual advantages between the parties when inter and intra-social network of SMEs are formed. It denotes the ability of the players to derive substantial and immeasurable advantages from their social networks, personal relationships and the quality of association (Portes, 1998). The social capital theory puts up an argument that individuals and organizations most often participate in social networks in order to make profits (Lin, 1999). The theory has its strength based on three assumptions namely (i) the more the networking, the greater the social capital, (ii) the greater the social capital, the higher the priority of the norm of equality (iii) the greater the social capital, the easier to mobilize support for problem solutions. As indicated by Schmid \& Robison (1995), the concept of social capital is made up of: expectations, obligations and information channels, trustworthiness of structures, norms, and effective sanctions. All these have a positive influence on SMEs growth. According to Davidsson \& Honig, (2003) SMEs are more probable to raise funds to finance their business growth better when they develop and maintain strong association to social networks. This is further clarified by Coleman et al., (2013) that social capital could be one of the vital resources which can enhance internal organizational trust through the bonding of actors, as well as by bridging external networks in order to provide useful financial resources. Evidence from previous studies conducted have come to a consensus that the driving force in social network theory is trust and fulfilment of obligation which go with sanctions (Coleman et al. 213; Knack \& Keefer; 1997; Lin, 1999). One significant beauty aspect of social capital theory as indicated by Kasekende \& Opondo (2003) is its ability to provide good results during information sharing that overcome information asymmetries problem, which is difficult to share information with potential financiers like banks.

More so, social capital networks from both internal and external sources have been found to be useful to all firms irrespective of their size. Markets are created and maintained through the network, at the same time it identifies business partners and potential investors for SMEs growth. When SMEs develop and maintain a good social network, they stand to benefit from social capital which will support their effort to secure finance 
for operations. This is made workable due to the fact that social capital builds trust among SMEs and their network partners. The social network takes the place of social insurance which translates into business insurance and provides access to pertinent information which SMEs need to embark on various business transactions (Spence et al., 2013). This strategy has been useful for banks which establish social networks with SMEs (DeYoung at al., 2012). It is prudent for SMEs to build networks with nonrival firms to enhance their ability and chance to enter into and observe contractual exchanges as well as legal protection from unscrupulous practices by other firms (Spence, et al., 2013) SMEs need to leverage their network relationships, which can increase their accessibility to novel sources of information to manage with turbulent environmental circumstances (Pinho, 2011). In a very clear and distinctive manner social network provided by organisations, community and friends and relatives are theorized to support the positive effects of entrepreneur characteristics like experience education and financial capital through trade-off. It is essential to apply this theory to identify and understand how social network can support entrepreneurs in sourcing for finance to fund their business growth especially in the wake of the Covid-19 pandemic which has equally affected the lending institutions.

\section{METHODOLOGY}

The study employed a qualitative and quantitative paradigm by collecting both qualitative and quantitative data in two townships (George and Furngroove) in Lusaka with a sample size of 98 SMEs out of 4,500 registered SMEs in Lusaka district as a whole (Ministry of Commerce, Trade and Industry Survey of 2018). Israel Yamane (1967) formula was used to determine the sampling criteria. Fifty (50) and Forty-eight (48) SMEs were sampled from George and Furngroove townships respectively using convenience and purposive sampling methods. Data was collected using 98 self-administered questionnaires complemented with interview guides. The questionnaires were distributed and returned by respondents at 100\%. The Statistical Package for Service Solutions (SPSS) was used to analyse descriptive statistics for questionnaires while content analysis was applied to qualitative data. The study concentrated on Bars and Liquors stores; Hair Salons and Barbershops; Restaurants /Take away; Stock Feed Shops; Computer /Phone accessories store and Supermarkets and Minimart Stores in the townships in question.

\section{FINDINGS}

\subsection{Respondents by Business Type}

\section{Figure 1: Number of respondents by type of SME/ Business}

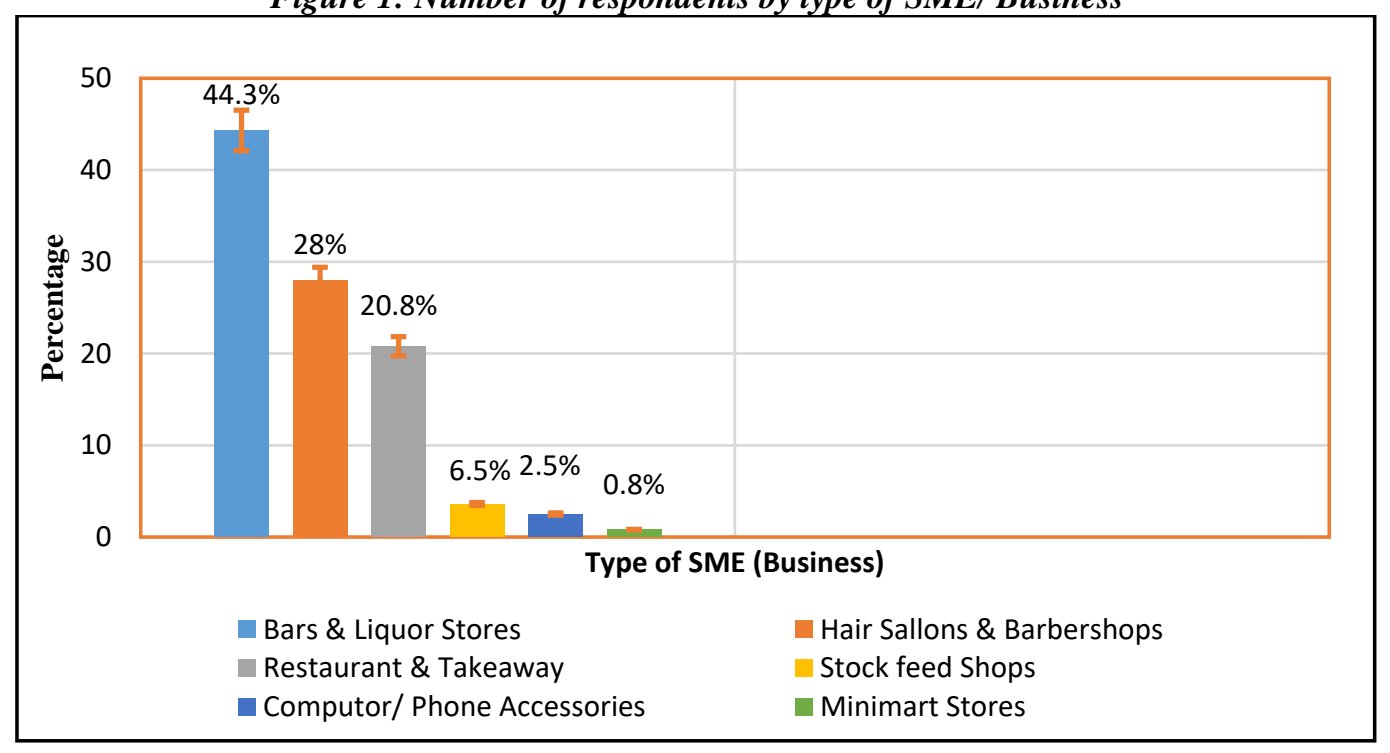

Source: Field Data (2021)

Figure 1 above shows that the majority of the respondents represented by $44.3 \%$ came from bars and liquors store owners; $28 \%$ of the respondents came from the hair salons and barbershops; $20.8 \%$ of the respondents were operating in restaurants/takeaways. Those in stock feeds were represented by $6.5 \%$ while $2.5 \%$ represented those in computer and phone accessories. Lastly, $0.8 \%$ of the respondents came from minimart stores.

\subsection{SMEs Bottlenecks Consequenced by Covid-19 Outbreak}

Statistical field data show that the major challenge faced by SMEs in George and Furngroove townships of Lusaka due to the outbreak of Covid-19 is the loss of customers represented by $48 \%$; reduced productivity due to workers working remotely accounting for $22 \%$ while high cost of doing business accounted for $21.6 \%$. Other challenges cited by SMEs were lack of access to finances accounting for $6.5 \%$; failure to quickly switch to digital technology accounting for $2.5 \%$ and supply chain disruption accounting for $0.9 \%$.

These findings are consistent with the Bank of Zambia (2020) survey on the challenges faced by SMEs which indicated that more than $86 \%$ of women-led firms reported decreased sales (a similar proportion of male led firms report the same) due to the decreased number of customers since the outbreak of the pandemic. The results also confirm CUTS (2020) findings that Justina's Agro- 
processing plant, which produces millet meal, porridge and sorghum meal, was temporarily closed during the initial months of the crisis and then was relocated to a larger facility to meet social distancing guidelines. New workers had to be trained and the cost of sourcing inputs from farmers who supply crops or livestock also increased.

\subsection{Impact of Covid-19 on SMEs}

\subsubsection{Impact of Covid - 19 on Monthly Revenues}

Field data indicate that about $62.8 \%$ of the business had revenue reduction of not more than $50 \%$ and around $2 \%$ of the businesses had zero revenue because they stopped operating completely. Besides, $32.6 \%$ of the business surveyed had their revenue reduced more than 50\%. Those whose revenue did not change accounted for $1 \%$. While only $1.6 \%$ of the businesses actually had an increase in revenue.

These results did not vary fundamentally from the study conducted by Varshney \& Vyas (2020) on the potential impacts of the pandemic on the MSMEs in South Africa. The results of the study indicated that the effects Covid - 19 pandemic on MSMEs was significant in that $69 \%$ of MSMEs reported a decrease in business revenue generation since the beginning of the coronavirus outbreak. The predominant reason for a fall in revenue was a decline in consumer demand for the products $(71 \%)$; followed by supply chain issues (15\%). Interestingly, the study further revealed that about $14 \%$ of the MMSEs reported an increase in revenue - these were mostly businesses that dealt with essential goods and services; delivery of foods and household goods, and security.

Further, the results of the study have been confirmed by Amin et al., (2020) who also conducted a study in India to assess the short- and long-term effects of the pandemic on the access to finances by SMEs. The results indicated that access to working capital, by far, was the most cited requirement $(71 \%)$ for businesses to grow and mitigate the adverse effects of the crisis. According to respondents, the least necessary requirement thus far was access to qualified workers and digital literacy skills. Despite the need for working capital, $73 \%$ of respondents have been unsuccessful in raising funds for their businesses to manage the impact of the pandemic.

\subsubsection{Impact of Covid -19 on the Operations of the Business}

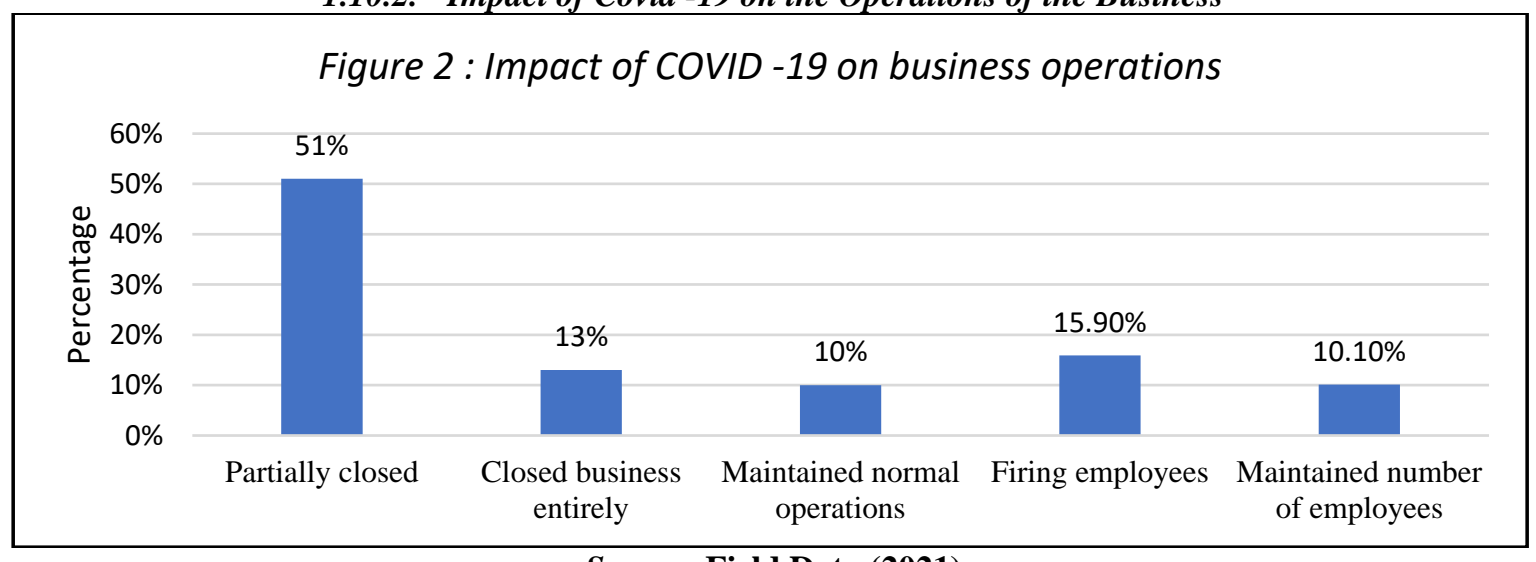

Source: Field Data (2021)

Figure 2 above indicates that $51 \%$ of businesses were partially closed while $13 \%$ of businesses closed entirely; $10 \%$ of businesses maintained their operations. Furthermore, $16 \%$ of the businesses fired their employees while 10\% of the businesses managed to maintain the same number of employees.

Qualitative responses from the SMEs indicated that the impact of Covid - 19 on SMEs included; total closure of business; revenue reduction; reduction in the number of employees and reduction in access to financial resources (such as loans) to finance their businesses.

\subsection{Government Relief to SMEs to Mitigate the Impact} of the Pandemic

Quantitative field data indicate that $57 \%$ of the respondents stated that the major relief or support provided by government to mitigate the impact of COVID-19 on their businesses was a stimulus package. Tax waiver represented by $28 \%$ and wage subsidies accounting for $2 \%$ were also relief provided by government. Other relief packages included loan facilities and loan grants accounting for $12 \%$ and $1 \%$ respectively. It was, however, qualitatively learnt that errors of inclusion and exclusion were apparently clear in the distribution of the said relief package.

Results on the relief provided by government to help SMEs mitigate the impacts of the pandemic indicate that government provided a stimulus package to help SMEs navigate through the impacts of the pandemic. However, some SMEs indicated that despite such an intervention being availed by government, they did not have an access to such a package because they did not meet the requirements to be beneficiaries. As such most of them closed the operations which now has a negative impact on their livelihood.

This implies that relief from government would help SMEs navigate through the impact of Covid - 19 on their businesses if proper distributive mechanisms were established. The Bank of Zambia report indicates that the government approved $\mathrm{K} 8$ billion kwacha (\$439 million) economic stimulus package financed through a COVID-19 bond in an effort to alleviate the pandemic's 
impact on SMEs. The government also announced a waiver of tax penalties and interest on outstanding tax liabilities resulting from the impact of COVID-19. Additionally, the Zambia Revenue Authority (ZRA) issued guidelines on the period of relief, waiver qualification criteria and other related modalities. This was in a bid to help the SMEs survive in the midst Covid - 19 Outbreak. Furthermore, the Bank of Zambia, which is the country's central bank, announced a series of regulatory relief measures for the banking sector in order to unleash financial liquidity into the market via reduced lending rates, among others. These relief measures are intended to also encourage banks, in turn, to provide financial relief to their borrowers (SMEs) (BOZ, 2020).

\subsection{Implications of Findings}

The glaring indications that as a result of Covid-19, businesses lost customers, reduced productivity due to workers working remotely and experienced high cost of doing business raise a very serious indictment on the prospects of the country meeting its brilliant aspirations of being a prosperous middleincome country as chronicled in its Vision 2030. This implies that SMEs have been badly hit by this pandemic and the chances of survival are lower especially for SMEs with lower working capital. Loss of customers would lead to a reduction in production and low sales and to survive, a business might decide to downsize the labour force. Firing of employees as well as total or partial closure of businesses imply that people's source of income reduced and that has a trickle-down effect on cost of living i.e. the cost of living has become higher for the affected SMEs and poverty can be the end result. Moreover, this becomes the easiest entry into the poverty vicious circle with labyrinthine exit modes.

\section{CONCLUSION AND RECOMMENDATIONS}

1.13 .

\section{Conclusion}

The study along with corroborative empirical literature has demonstrated beyond reasonable doubts that Covid-19 has had a devastating effect on business operations in general and financial liquidity of entities and individuals in particular. It, therefore, goes without saying that this pandemic has further ditched many into high poverty levels; unemployment and further widened the gap between the rich and the poor. Ultimately, the prospects of the country to achieve a prosperous middle income status by 2030 have further been depressed and eclipsed. Against this background, gigantic and deterministic measures are necessary to resuscitate the situation to normalcy on both a short and long-term basis.

\subsection{4}

\section{Recommendation $(s)$}

The government through the Ministry of Commerce, Trade and Industry needs to set up a well-structured, objective, focused and co-ordinated policy approach and package to address the current impact of the pandemic faced by SMEs. Specifically, government should at all cost avoid top-down policy imperatives and dogmas as the same do not yield much desired results. There is need for thorough consultations with all relevant institutions and stakeholders when developing an emergency pandemic policy response and package such as the K10 billion (\$500-Million) stimulus package aimed at providing medium term liquidity facility to help enterprises cope with the pandemic. There should have been clarity as to which SMEs and how much would be assigned to each entity based on assessed level of impact to avoid shooting in the dark as the case has been. To this end, there is need for an audit into the Covid-19 relief package to determine its actual disbursement and to what extend the same has met the intended objectives. There is also need for government through the Ministry of Commerce, Trade and Industry to revamp other existing platforms where businesses can find opportunities to contribute to the fight against Covid-19 and learn how other companies are adapting their businesses to Covid19 successfully. Such 'success stories' of those who managed to meet demand for goods and services urged by the pandemic would be both motivational and guidance material for those who still struggle through the situation. Finally, the government can make use of available statutory agencies like the Zambia Development Agency (ZDA), Citizens Economic Empowerment Commission (CEEC) etc to channel such resources in order to avoid politicization of development funds aimed at empowering citizens.

\section{REFERENCES}

[1] Abiad, A., 2020. "The Economic Impact of the COVID-19 Outbreak on Developing Asia," Asia Development Bank (ADB) Briefs, No. 128, Available atwww.adb.org/publications/series/adb-briefs. s.l.:s.n.

[2] Adb, 2020. The Economic Impact of the COVID-19 Outbreak on Developing Asia.. s.l.:s.n.

[3] Amin, Atkeson, A. \& Ahmad, T., 2020. What will be the economic impact of COVID-19 in the US? Rough estimates of disease scenarios. National Bureau of Economic Research. https://doi.org/10.3386/w26867. s.1.:s.n.

[4] Baldwin, R., Weder \& di Mauro, B., 2020. Economics in the time of COVID19. CEPR Press.. s.1.:s.n.

[5] Balla-Elliott, D. et al., 2020. Business reopening decisions and demand forecasts during the COVID-19 pandemic. SSRN Electronic Journal.. s.l.:s.n.

[6] Banking and Insurance, 2020. Banking and Insurance Academic Journal Vol 2, No. 6; June-2020; ISSN (5304 - 3433) p - ISSN 7533 - 6011. s.1.:s.n.

[7] Bebbington, A. \& Perreault, T., 1999. 'Social capital, development and access to resources in Highland Ecuador' in Economic Geography. 75(4). 395-418.. s.1.:s.n.

[8] Best \& Kahn, 2009. Understanding Development: The Absence of Power among Local NGOs in Africa. Oxford: James Currey. s.1.:s.n.

[9] BOZ, 2020. How can we help small business affected by the COVID-19 crisis? Retrieved June 24, 2020. s.1.:s.n.

[10] Coleman, J., 2000. 'Social Capital in the Creation of Human Capital' in The American Journal of Sociology.94. Supplement: Organizations and Institutions: Sociological and Economic Approaches to the Analysis of Social Structure. S95-S120. s.l.:s.n.

[11] CUTS, 2020. "Impact of COVID-19 pandemic on micro, small, and mediumsized enterprises operating in Pakistan", Research in Globalization, Vol. 2, p. 100018. s.1.:s.n.

[12] Dixon \& Chris , 2003. Rural Development in the Third World. Routledge, London.. s.1.:s.n.

[13] ECA \& IEC, 2020. Insights on African Businesses' Reaction and Outlook to COVID 19's. IEC Mauritius, \&ECA, Addis Ababa, 30th April 2020.. s.1.:s.n.

[14] FSD Zambia, 2017. Access to Finance: SME perceptions of Financial Service Providers, December 2017. s.1.:s.n.

[15] International Labour Organization, 2020. ILO monitor: COVID-19 and the world of work, 5th edition.. s.1.:s.n.

[16] Kuckertz, A. et al., 2020. "Startups in times of crisis - a rapid response to the COVID-19 pandemic", Journal of Business VenturingInsights,Vol.1. s.1.:s.n.

[17] McKibbin, W. \& Fernando, R., 2020. "The Global Macroeconomic Impacts of COVID-19: Seven Scenarios," Available at https://www.brookings.edu/wpcontent/uploads/2020/03/20200302_COVID19.pdf. s.1.:s.n. 
[18] Ministry of Commerce, Trade and Industry, 2020. The Micro, Small and Medium Enterprise Development Policy amid COVID - 19, Lusaka. s.1.:s.n.

[19] OECD , 2020. "Supporting people and companies to deal with the Covid-19 virus: Options for an immediate employment and social-policy response" Available at www.oecd.org/employment/. s.l.:s.n.

[20] OECD, 2020. OECD SME and entrepreneurship outlook 2020. OECD Publishing.. s.1.:s.n.

[21] Oluoch, J. O., 2016. The Impact of Cash Management Practices on Performance of SMEs: A Survey of SMEs in Eldoret Central Business District. Journal of Economics and Finance, 7(6), pp 2321-5925.. s.1.:s.n.

[22] Portes, A., 1998. 'Social capital: its origins and applications in modern sociology' in Annual Review of Sociology. 24.1-24.. s.1.:s.n.

[23] Reeves, M., Carlsson-Szlezak, P., Whitaker, K. \& Abraham, M., 2020. Sensing and shaping the post-COVID era. Henderson Institute, Boston Consulting Group.. s.l.:s.n.

[24] Spence, Schmidpeter \& Habisch , 2013. Social Capital: a peg to hang any theory on. Paper prepared for the Centre for Research on Latin America and the Caribbean (CERLAC).. s.1.:s.n.

[25] Stacey, 2011. Business process reengineering on sme's: Evidence from Romanian sme's. In Proceedings of the 9th International Management the 9th International Management. s.1.:s.n.

[26] UNCTAD, 2020. "Containing the spread of panic is as important as stopping the coronavirus itself. Madrid, data updated on 20/01/2020.. s.1.:s.n.

[27] UNDP, 2020. s.1.:s.n.

[28] UNECA , 2020. Impact Assessment of COVID-19: The Case Study of East Africa, UNECA Sub-Regional Office foEastern Africa, Kigali.. s.1.:s.n.

[29] Varshney, D. \& Varshney, N., 2020. The effect of resilience on performance and job satisfaction among construction managers in Saudi Arabia. Global Business And Organizational Excellence, 36(5), 36-45.. s.1.:s.n.

[30] World Bank , 2020a. The Economic Impact of the 2020 COVID - 19 Epidemic: Short and Medium Term Estimates for European Countries, World Bank Group, Washington, DC.. s.1.:s.n.
[31] World Bank Group, 2020b. " Equitable Growth, Finance and Institutions: COVID $19 \quad$ Notes, Finance http://pubdocs.worldbank.org/en/879461586478617078/COVID-19Outbreak-Support-to the Firm. s.1.:s.n.

[32] World Bank, 2020c. The COVID-19 (coronavirus) outbreak has set off the first recession in the Sub-Saharan Africa region in 25 years, Geneva: World Bank.. s.1.:s.n

[33] World Bank, 2020d. External linkages and innovation in small and mediumsized enterprises. R\&D Management, 21(2), 125-138.. s.1.:s.n.

[34] World Bank, 2020e. Small and medium enterprises (SMEs) finance.. s.1.:s.n.

[35] World Health Organization, 2020. Coronavirus disease (COVID-19) pandemic.. s.1.:s.n.

[36] Zambia Institute of Public Health, 2020. Zambia Institute of Public HealthCOVID-19 Situation Reports (SitReps) - 2020/2021. s.1.:s.n.

[37] ZDA, 2020. Report on the Review of the Development Agency (ZDA) Act 2020. Zambia Business Forum. s.1.:s.n.

\section{AUTHORS}

First Author - Dr. Chrine Hapompwe, Lecturer - Faculty of Social Sciences: Cavendish University Zambia, chapompwe@cavendish.co.zm

Second Author - Caroline Simushi, Post Graduate Student Department of Development Studies: Cavendish University Zambia, cs57732@students.cavendish.co.zm

Third Author - Kiru Sichoongwe, PhD Candidate - National School of Development: Peking University, China., sichoongwe2019@isscad.pku.edu.cn 